ФОРМУВАННЯ ВИХОВНОГО ІДЕАЛУ У СИСТЕМІ

НАУКОВО-ПЕДАГОГІЧНОГО ДІАЛОГУ АКАДЕМІКА Н.Г. НИЧКАЛО

ТА ДОКТОРА ПЕДАГОГІЧНИХ НАУК Л.М. ЄРШОВОЇ

\title{
FORMATION OF EDUCATIONAL IDEAL IN THE SYSTEM OF SCIENTIFIC-PEDAGOGICAL DIALOGUE OF ACADEMICIAN N.G. NICHKALO AND DOCTOR OF PEDAGOGICAL SCIENCES L.M. ERSHOVA
}

На прикладі творчого науково-педагогічного діалогу академіка Н.Г. Ничкало та доктора педагогічних наук Л.м. Єршової досліджується система фрормування виховного ідеалу у системі сучасної особистісно зорієнтованої освіти. У статті порушено проблеми науково-теоретичних аспектів алгоритму інноваційних змін у системі сучасно школи. Науково-педагогічна школа академіка Н.Г. Ничкало найважливішими принципами декларує утвердження виховного ідеалу на всіх етапах сучасної освіти, створює передумови для утвердження якісних інноваційних процесів педагогічної взаємодії у системі «освіта - суспільство». У дослідженні розглядаються проблеми оновлення і впровадження інноваційного змісту освіти, переформатування системи вимог до знань та умінь вихования вищої школи, максимальна взаємодія між практикою і навчанням, які формуються на основі добре продуманого культурологічного впливу, розглядається система становлення культурологічноі компетентності, яка є наслідком симбіозу зусиль усіх ланок навчально-виховної діяльності сучасної школи. Розглядається система формування людської індивідуальності у системі особистісно зорієнтованої освіти. На прикладі творчого науково-педагогічного діалогу академіка Н.Г. Ничкало та доктора педагогічних наук Л.М. Єршової аналізується вплив предметів гуманітарного циклу на формування особистих якостей студента: чілеспрямованої волі, добре продуманої діі і психологічно-вольових зусиль. Розглядається парадигма людиноцентричної педагогіки у системі найважливіших напрямів: реалізації творчих можливостей людськоі індивідуальності, які мають бути максимально корисними як для кожної конкретної людини, так і для цілого людства.

Досліджуються загальні тенденції розвитку сучасної педагогіки, що знайшли відображення у науково-методичному доробку академіка Н.Г. Ничкало. Розглядаються проблеми взаємозумовленості розвитку культурологічної компетентності та парадигми сучасної особистісно зорієнтованої освіти, що складає основу людиноцентричної педагогіки; аналізується системне еволюційне осмислення розвитку особистості сучасних студентів, аналізується сутність та деякі наукові засоби утвердження культурологічно зорієнтованої особистості у своєму духовному призначенні, розглядаються тенденції розвитку культурологічних засад сучасної професійної школи.

Ключові слова: культурологічна компетентність, культурологічний світогляд, дискурс, психологічна безпека суспільства, культурологічна свідомість, мистецтво спілкування, культурологічне середовище, психологічний захист особистості.

On the example of creative scientific-pedagogical dialogue of academician N.G. Nychkalo and Doctor of Pedagogical Sciences Lershova Ershova the system of formation of educational ideal in the system of modern personally oriented education is investigated. The article deals with the problems of scientific and theoretical aspects of the algorithm of innovative changes in the modern school system. School of Education and Academician N.G. Nychkalo the most important principles declare the establishment of the educational ideal at all stages of modern education, creates the preconditions for the approval of high-quality innovative processes of pedagogical interaction in the system "education - society". The study examines the problems of updating and implementing innovative content of education, reformatting the system of requirements for knowledge and skills of high school graduates, maximum interaction between practice and learning, which are formed on the basis of wellthought-out cultural impact, the system of cultural competence formation, which is a consequence of all symbiosis, is considered. links of educational activities of the modern school. The system of formation of human personality in the system of personally oriented education is considered. On the example of creative scientific-pedagogical dialogue of academician N.G. Nychkalo and Doctor of Pedagogical Sciences L.M. Ershova influence of subjects of the humanitarian cycle on formation of personal qualities of the student is analyzed: purposeful will, well thought out action and psychological and volitional efforts. The paradigm of human-centric pedagogy in the system of the most important directions is considered: realization of creative possibilities of human individuality, which should be maximally useful both for each individual person and for the whole of humanity.

The general tendencies of development of modern pedagogics are investigated, which are reflected in the scientific and methodological development of the academician N.G. Nychkalo. The problems of interdependence of the development of cultural competence and the paradigm of modern personally oriented education are considered, which forms the basis of human-centric pedagogy; systematic evolutionary understanding of the development of personality of modern students is analyzed.

Key words: cultural competence, cultural worldview, discourse, psychological safety of society, cultural consciousness, art of communication, cultural environment, psychological protection of the individual.
Львівського національного університету імені Івана Франка кого вивчення. На прикладі творчого науковопедагогічного діалогу академіка Н.Г. Ничкало та доктора педагогічних наук Л.М. Єршової досліджу- станка проблеми. Пара досвіду науково-педагогічних шкіл сучасної інноваційної педагогіки ще не стала предметом широ- 
ється фрормування виховного ідеалу сучасності у контексті «гармонія комунікативного соціуму», що дає гарантію можливості та використання повного обсягу духовно-екзистенційних здобутків у вільному синтезу, в духовному зв'язку традицій та сьогодення і $\epsilon$ передумовою та запорукою природного, самобутнього, вільного розвитку як економічної, так і соціальної сфери суспільства.

Виділення не вирішених раніше частин загальної проблеми. Наукова новизна. На прикладі творчого науково-педагогічного діалогу академіка Н.Г. Ничкало та доктора педагогічних наук Л.М. Єршової ми спостерігаємо, як специфріка інноваційної культурологічної парадигми полягає у тому, що ґрунтується на різноплановому амбівалентному поєднанні протилежних тенденцій становлення та постійного розвитку сучасної інноваційної культури: універсальної та партикуляристської. Дослідження проблеми сучасного виховного ідеалу полягає у тому, що на даному етапі йде творення новітнього культурологічного канону: у процесі накопичення знань, фрактів, вивчення всього, що може бути корисним у процесі пізнання світу і самого індивіда у цьому світі.

Для вирішення окреслених завдань та досягнення мети основними методами дослідження були загальнонаукові: аналіз, синтез, порівняння та узагальнення. Також використовувався семантичний, синенергетичний, культурологічний та герменевтичний методи. Зазначений методологічний підхід дозволив проаналізувати системне творення інфрормаційної безпеки суспільства як складника загальної гуманітарної парадигми сучасної інноваційної освіти.

Постановка завдання - на прикладі творчого науково-педагогічного діалогу академіка Н.Г. Ничкало та доктора педагогічних наук Л.М. Єршової показати становлення виховного ідеалу сучасної особистісно зорієнтованої освіти.

Аналіз останніх досліджень та публікацій. На нинішній час існує цілий ряд досліджень формування виховного ідеалу сучасного вихованця особистісно-зорієнтованої освіти, фрормування культурологічної компетентності як інноваційної парадигми сучасності досліджують у своїх працях І.Д. Бех, В.П. Андрущенко, Н.С. Барбелко, І.Д. Бех, І.М. Вегеш, Т.О. Дороніна, В.Г. Кремінь, С.У. Гончаренко, І.А. Зязюн, Н.Г. Ничкало, В.О. Огнев'юк, Т.М. Герлянд, Л.Д. Герганов, М.Б. Євтух, Л.М. Єршова, А.А. Каленський, П.Г. Лузан, Н.П. Павлик, Л.А. Пригодій, О.П. Проніков, В.Ф. Орлов, І.Д. Пасічник, Л.П. Пуховська, В.О. Радкевич, Л.М. Романишина, С.О. Сисоєва, М.Т. Теловата, А.Т. Терентьєва, О.І. Щербак, В.В. Ягупов та ін. Наукові проблеми культурологічної підготовки студентів, що досліджуються у сучасній педагогічній науці, професійної освіти у стратегії духовно-екзистенційної боротьби за онов- лення суспільства (В.П. Андрущенко, В.Г. Кремінь, І.А. Зязюн, М.Б. Євтух, І.А. Сліпухіна, Г.Л. Токмань, O.І. Шапран та інші).

І.Д. Бех накреслив алгоритм фрормування духовно-екзистенційних основ особистості у системному відтворенні «від культури мислення до культури духовного переживання». У статті «Духовна особистість у контексті освітніх викликів» видатний учений І.Д. Бех наголошує: «Багатовікове відчуження людини від справжніх духовних цінностей призвело до кризових явищ, пов'язаних із занепадом духовно-моральних ідеалів, посиленням зла і насильства. Девальвація духовних цінностей суттєво вплинула на посилення тенденції зростання жорстокого індивідуалізму, прагматизму, зверхнього ставлення до інших людей та приниження їхньої гідності, зневаги до рідної культури та історико-культурних традицій» [4, ст. 3].

Виклад основного матеріалу. За концептуальними засадами науково-педагогічної школи академіка Н.Г. Ничкало, система вищої профресійної освіти - ключовий чинник успіху розвитку країни. Архетип творчого діалогу академіка Н.Г. Ничкало та доктора педагогічних наук Л.М. Єршової яскраве підтвердження тих прогресивних тенденцій сучасного духовного розвитку суспільства.

Зумовлена розвитком постійного накопичення нових інформаційних технологій культурологічна індивідуалізація призвела до постійного зростання ролі культурологічної парадигми сучасності у долі кожної особистості як суб'єкта культурологічної творчої діяльності. Проблема творення виховного ідеалу сучасності $€$ надзвичайно актуальною на всіх етапах розвитку сьогоднішньої освіти.

На цьому фроні спостерігається активізація культурологічних контактів, які $€$ основою взаємопроникнення культурологічних смислів. Світоглядне напруження, втілене у постійному протиборстві двох протилежних моделей культурного буття, - глобалістики та індивідуалізації - фрормує унісікований синтез культур, у якому кожна індивідуальність знаходить можливість своєї творчої реалізації.

На прикладі творчого науково-педагогічного діалогу академіка Н.Г. Ничкало та доктора педагогічних наук Л.М. Єршової бачимо, як у цій інноваційній педагогічній системі важливим $€$ не проста емпірична розповідь про видатних людей свого часу, а несподіваний ракурс подачі у тому чи іншому контексті. Проблема «людина і суспільство», «людина і громадська чи політична діяльність» в умовах сучасного духовного життя логічніше трансорормується як «індивідуальність індивідуальність як проблема творчої взаємодії».

Тому система вищої освіти - ключовий чинник успіху розвитку країни. На відміну від попередніх десятиліть, коли для потужного зростання були важливі природні й виробничі ресурси, зараз най- 
головніше - людський капітал. Якщо є талановиті та кваліфіковані кадри, то розвиток країни буде стабільним, а виховання таких кадрів неможливе без фрормування їх професійної, а відтак і культурологічної компетентності. В освіті та науці важливий ефект критичної маси: чим більше талантів, тим вища продуктивність кожного з них і тим конкурентоспроможнішою є країна.

«Людей мільйони і мільйони слів, а ти їх маєш вимовити вперше», - ці слова Ліни Костенко характеризують нетривіальну унікальність художнього мислення, на піку якого письменник щораз долає і несе свій тернистий творчий біль від основи аж до вершин Голгофи власного творення. Педагогіка як наука, щораз інтерпретуючи духовний світ свого духовного світоча, аби сягнути заповітної вершини, змушена розпочинати із найперших праоснов.

На прикладі творчого науково-педагогічного діалогу академіка Н.Г. Ничкало та доктора педагогічних наук Л.М. Єршової можемо виокремити наступні загальні тенденції сучасного архетипу виховного ідеалу, який найбільше фрормується у системі культурологічної площини.

Особливість формування культурологічної підготовки майбутніх економістів: на мікрорівні загальна культура особистості ( $€$ передумовою та основою фрормування загальної культури майбутніх економістів); фрормування навичок повсякденно виправданої поведінки у побуті та професійній діяльності; фрормування уміння передбачати соціальні наслідки просресійно-срахових рішень; фрормування переконання необхідності використання у професійній діяльності креативних технологій; на мезорівні - урахування у робочих програмах професійно орієнтованих дисциплін змісту складників сталого розвитку; використання інноваційних педагогічних технологій освітнього процесу для інтеграції економічного та соціального складників сталого розвитку; на макрорівні - фрормування системи уявлень про стратегію сталого розвитку суспільства; урахування морально-естетичного імперативу у процесі реалізації економічних інтересів підприємства, регіону, держави; професійна підготовка майбутніх економістів передбачає прогноз наслідків впливу економічної діяльності на розвиток суспільства.

Як показує творчий науково-педагогічний діалог академіка Н.Г. Ничкало та доктора педагогічних наук Л.М. Єршової, дослідження з формування культурологічної підготовки студентів сучасних закладів освіти різноманітні, охоплюють багато аспектів цієї проблеми. Профресійна компетенція професійної культурологічної підготовки, на наш погляд, - це готовність кожного фахівця реалізовувати у практичній діяльності основи набутої фрахової професійної компетентності, тобто профресійна компетенція стосується знань та умінь кожного індивіда, а процес їх реалізації у конкретній діяльності $€$ профресійною компетентністю.

Світ швидко змінюється, і необхідно бути достатньо мобільними, щоб не тільки перебудовувати свою економіку, а й мати достатню підготовку, аби працювати в умовах нинішніх світових тенденцій. Таким чином можна досягти успіху в створенні й отриманні прибутку в нових секторах до того як їх освоять інші.

На прикладі творчого науково-педагогічного діалогу академіка Н.Г. Ничкало та доктора педагогічних наук Л.М. Єршової можемо стверджувати, що увесь науковий досвід у системі творення особистісного архетипу розпочинається із практичного шляху, який проходить кожен, кому послано цей терновий вінець художнього світобачення. В розрізі віків і тисячоліть такі творчі метаморфози нагадують розвиток ембріона в утробі матері, який упродовж кількох місяців відтворює історію еволюції людства від самих початків. Отже, педагогічна наука як універсальна система вираження й усвідомлення логічного та духовно-культурного досвіду $€$ співтворчою із мистецтвом даністю. Без сумніву, аналітичні засоби у парадигмі виховного процесу мають пріоритетне значення: сумарне значення складників збагачується розмаїттям виражально-смислових прийомів індивідуалізації процесів, кожен з яких характеризується індивідуальною неповторністю й орієнтацією на розвиток талантів.

На прикладі творчого науково-педагогічного діалогу академіка Н.Г. Ничкало та доктора педагогічних наук Л.М. Єршової можемо наголошувати, що закоріненість у власну історію і свій духовний імператив стали джерелом народження новітніх духовних фрорм буття, коли людська індивідуальність сягнула усвідомлення власної неповторності у космогонічному центрі Всесвіту. Особистісно зорієнтовану педагогічну систему вирізняє наступна особливість: все підпорядковане творенню людського духовного світу, і як наслідок значно активніше фрормуються професійні знання і розвивається воля, без якої неможливою є продуктивна реалізація на практиці здобутих теоретичних знань та наукових здобутків.

Як показує вивчення творчого науково-педагогічного діалогу академіка Н.Г. Ничкало та доктора педагогічних наук Л.М. Єршової, культурологічна компетентність із чітко вираженою системою аксіологічних цінностей дозволяє сформувати міцну мотиваційну основу професійної діяльності. Власне культурологія більше, ніж будь-яка інша сорера глибокого внутрішнього світу людини, забезпечує постійну соціальну стійкість у системі відносин людини і суспільства, людини і сорери професійної діяльності, людини й інших людей. Така система також ефективно впливає на фрормування моральної свідомості, самосвідомості, 
багатогранних профресійних якостей студента технічного університету. Гуманітаризація освіти $€$ одним з основних чинників гуманізації суспільства, оскільки через систему освіти забезпечується процес соціалізації, професіоналізації індивіда, і саме в цій структурі він засвоює норми, правила і цінності духовної культури суспільства.

На прикладі творчого науково-педагогічного діалогу академіка Н.Г. Ничкало та доктора педагогічних наук Л.М. Єршової ми можемо стверджувати, що модернізація освіти спонукає звернути серйозну увагу на гуманітарно-культурологічні підходи у підготовці до життя молоді, на розвиток молодих людей як суб'єктів не лише професійної, а й гуманітарної культури суспільства. Якісні зміни у розвитку сучасного мистецтва як основного фрундаменту для гуманітаризації студентів технічних університетів змушують по-новому подивитися на дидактичні можливості цих духовних явищ суспільства. Культурологічна підготовка студентів технічних університетів створює основу для реалізації компетентнісного підходу у практиці професійної освіти, орієнтується на кінцевий результат освітнього процесу та спрямовується на фрормування у випускника готовності ефективно організовувати внутрішні (знання, уміння, цінності, психологічні особливості тощо) і зовнішні (інорормаційні, людські, матеріальні тощо) ресурси для досягнення поставленої мети.

За нашим баченням, сталий розвиток - це розвиток людства, коли задоволення потреб сучасних поколінь здійснюється без шкоди для майбутніх і не руйнує своєї природної основи, забезпечуючи безперервний прогрес цивілізації, розвиток суспільства, що заснований на нормах та цінностях загальнолюдської культури.

Висновки та перспективи наступних досліджень. На прикладі вивчення творчого науковопедагогічного діалогу академіка Н.Г. Ничкало та доктора педагогічних наук Л.М. Єршової ми можемо стверджувати, що основою фрормування сучасного виховного ідеалу є система культурологічної підготовки, у якій загальні та профресійні принципи перебувають у діалектичній гармоній єдності. Сучасний студент потребує емоційного зацікавлення у пізнанні цих явищ. Більше того, інноваційне використання окремих предметів гуманітарного циклу буде корисним не лише для гуманітарного виховання студента, а і для активізації мисленнєвої діяльності, пошуків внутрішніх ресурсів для ефективного навчання, а згодом і для продуктивної праці. Якісні зміни у розвитку сучасного мистецтва як основного фрундаменту для гуманітаризації студентів технічних університетів змушують по-новому подивитися на дидактичні можливості цих духовних явищ суспільства.

\section{БІБЛІОГРАФІЧНИЙ СПИСОК:}

1. Бех І. Д. «Духовна особистість у контексті освітніх викликів» // Рідна школа. -2019, № 1. - С. 3-7.

2. Єршова Л. М. Трансорормація виховного ідеалу в Україні (XIX - початок XX століття) : Київський, Одеський, Харківський навчальні округи : [монографрія] / Л. Єршова. - Житомир : Видавець Євенок О.О., 2015. - 642 c.

3. Єршова Л. М. Основи педагогіки та психології: практикум для організації самостійної роботи студентів негуманітарних вищих закладів освіти : [ навч.метод. посібн.] / Л.М. Єршова, О.М. Пелехатий. Житомир: Полісся, 2010. - 112 с.

4. Єршова Л. М. Мовний патріотизм у змісті українського виховного ідеалу / Л. М. Єршова // Вісник Житомирського державного університету імені Івана Франка. - 2013. - Вип. 3 (69). - С. 79-83.

5. Ничкало Н.Г. Профресійне навчання дорослого населення: теоретико-методологічні засади. - Національна академія пед. наук України, Інститут педагогічної освіти і освіти дорослих. - К., Кіровоград: Імекс, 2013.- 263 с.

6. Ничкало Н.Г. Теоретико-методологічні проблеми розвитку досліджень з педагогіки і психології профресійної освіти // Діалог культур: Україна у світовому контексті: матеріали 1 міжн. фріл.-культ. читань. м. Львів, 25-26 квітня 1996 р. - Л., 1996. - С. 3-10.

7. Ничкало Н.Г., Гончаренко С.У., Радкевич В.О. Державні стандарти професійної освіти: теорія і методика. - Хмельницький, ТУП, 2002. -334 с.

8. Ничкало Н.Г. Трансфрормація професійно-технічної освіти в Україні. - К.: Пед. думка, 2008. - 199 с. 